\title{
Optimal Liberalization of Financial Markets
}

\author{
Khang Min Lee and Nathalie Moyen*
}

\begin{abstract}
This paper shows that the type of production technology, specifically whether it exhibits decreasing returns to scale in capital, is an important factor in evaluating the welfare gain from liberalizing financial markets, and hence the optimal financial structure for a country. As financial markets become completely liberalized, countries gain from a better capital allocation as a result of improved risk sharing, but the less wealthy country can no longer profit from borrowing abroad at a lower rate and reinvesting at home in the technology with a higher expected rate of return. With decreasing (rather than constant) returns to capital, the gain from risk sharing is more likely to dominate the loss of the difference between the borrowing rate abroad and the decreasing (rather than constant) reinvestment rate at home. Our analysis suggests that complete liberalization is likely to be optimal for less wealthy countries unless their labor endowment is large, their mean productivity is large, or initial holdings by foreigners are small, as is currently the case in China.
\end{abstract}

Lee is from the Royal Bank of Canada, and Moyen is from the Leeds School of Business at the University of Colorado. Please direct correspondence to Nathalie Moyen, Leeds School of Business, 419 UCB, University of Colorado, Boulder, CO 80309; Moyen@Colorado.Edu; 303 735-4931 (phone), 303 4925962 (fax). 


\section{Introduction}

Financial markets in many large economies have been increasingly liberalized over the last thirty years since the breakdown of the Bretton Woods system. The empirical evidence, including Levine and Zervos (1998), Bekaert et al. (2001), Edwards (2001), and Rajan and Zingales (2003), shows that this liberalization has stimulated economic growth. However, it is not clear that liberalization has improved the welfare of each economy. Past experiences of financial crises within blocs of emerging markets with free capital flows (such as in Asia and Latin America) have cast doubts on the benefits of world financial integration.

The role of financial markets in sharing production risks across countries is well understood. The early literature, including Subrahmanyam (1975a, 1975b), Errunza and Losq (1985, 1989), Eun and Janakiramanan (1986), Merton (1987), Hietala (1989), and Bergstrom et al. (1993), examines the effect of financial markets segmentation on portfolio choices and welfare in a static mean-variance framework. More recently, the literature has quantified the welfare gain from international risk sharing; see Brennan and Solnik (1989), Cole and Obstfeld (1991), Backus et al. (1992), van Wincoop (1994, 1996, 1999), Obstfeld (1994a, 1994b, 1995), Kose (1995), Mendoza (1995), Shiller and Athanasoulis (1995), Tesar (1995), Lewis (1996), Devereux and Lee (1999), Kubler and Schmedders (2001), and Kim, Kim and Levine (2003). The magnitude of this gain is very sensitive to assumptions and parameters of the model. In general, the welfare gain is large, and it increases when investors are more risk-averse or when the ability to share risk expands the production frontier with riskier, higher expected returns investment.

The welfare gain generated by moving from financial autarky to complete liberalization has therefore been studied under various frameworks, under both ideal and less-than-perfect conditions in exchange and linear production economies. However, there is no consensus on the welfare consequences of moving from partially liberalized financial markets to completely liberalized ones. Basak (1996) and Devereux and Saito (1997) show that the increased degree of liberalization may not always improve the welfare in each country. In fact, the less wealthy country may be worse off with full liberalization. With partial liberalization, the less wealthy country can borrow abroad at a lower rate and invest at home at a higher rate. The gain from the difference between the borrowing rate and the reinvestment rate may well outweigh the loss from imperfect risk sharing. Partial liberalization may therefore be the optimal financial market structure for some countries. 
In this paper, we relate the empirical evidence to the theoretical literature on the liberalization of financial markets by focusing on the macroeconomic fundamentals of production. Specifically, we examine how the welfare gain from liberalization is affected by returns to capital in the production technology. Our results complement those of Basak (1996) and Devereux and Saito (1997). Like Basak (1996) and Devereux and Saito (1997), we focus on the endogenous interest rate as an additional channel of influence for financial markets. However, in contrast to Basak (1996), who assumes exogenous returns in a portfolio model, and Devereux and Saito (1997), who assume a very special case of linear production technology in an investment model, we allow the marginal product of capital to depend on the investment decision by specifying decreasing returns to scale. ${ }^{1}$ As it turns out, the endogeneity of the marginal product of capital plays an important role in evaluating the welfare implications of liberalizing financial markets. When the marginal return decreases with capital, any gain from being able to borrow capital abroad at a lower risk-free rate to reinvest in the home production falls with every additional unit of capital and reduces any potential benefit derived by the less wealthy country from its partially liberalized financial markets.

The effect of decreasing returns to capital can be counteracted by a higher labor endowment, a higher mean productivity of the technology, or smaller initial holdings by foreigners. In those cases, it may be optimal for the less wealthy country to close its financial markets to foreign investors. Indeed, our numerical analysis, where China represents the less wealthy region and the advanced economies of the US and the EU represent the wealthier region, shows that the optimal financial market structure for China would allow no foreign access to domestic stock and loan markets.

The rest of the paper is organized as follows. The next section describes the model. Section 3 characterizes the equilibrium. Section 4 presents a special case of an analytical solution and reports the numerical results of the general model. The last section concludes.

\footnotetext{
${ }^{1}$ The appendix shows that our portfolio model is equivalent to an investment model when returns are linear in capital. Our results in the special case of a linear production technology are therefore comparable to those of the previous literature.
} 


\section{The Model}

The model describes a two-period ( $t=0$ and 1), one-good production economy. It is based on Sellin and Werner's (1993) model with an endogenous interest rate, but separates the household's portfolio choice from the firm's investment decision. ${ }^{2}$ There are two countries in our economy, home and foreign ( $i=1$ and 2$)$, with a representative household and firm in each country.

\subsection{The household's portfolio choices}

At time 0 , each household $i$ chooses its consumption profile $\left\{c_{i}(0), c_{i}(1, s)\right\}$, its holding of firm $j$ 's stock $a_{i j}$, and its amount to borrow or lend $b_{i}$, to maximize expected utility, given the budget constraint in each period. The household problem is written as

$$
\underset{c_{i}(0), c_{i}(1, s), a_{i j}, b_{i}}{\operatorname{Max}} \frac{c_{i}(0)^{1-\eta}}{1-\eta}+\beta E_{0}\left[\frac{c_{i}(1, s)^{1-\eta}}{1-\eta}\right],
$$

subject to the time 0 and time 1 budget constraints

$$
\begin{aligned}
& c_{i}(0)+\sum_{j=1}^{2} a_{i j} p_{j}+b_{i}=d_{i}(0)+p_{i}, \\
& c_{i}(1, s)=\sum_{j=1}^{2} a_{i j} d_{j}(1, s)+b_{i}(1+r),
\end{aligned}
$$

where $s$ represents the state of the world, $\eta$ the constant relative risk aversion parameter, $\beta$ the time preference factor, $p_{i}$ the stock price of firm $i,\left\{d_{i}(0), d_{i}(1, s)\right\}$ the dividend payment profile of firm $i$ 's stock, and $r$ the risk-free rate of return.

The budget constraint (2) assumes that the home (foreign) household owns the home (foreign) firm in the initial period. The budget constraints (2) and (3) assume that financial markets in both countries are perfectly open, so that households can borrow from or lend to each other, as well as trade in the claims of both firms. The expenditure for household $i$ in the initial period consists of its consumption in the period, the cost of purchasing shares in the local and foreign stock markets, and the amount it lends in the international loans market. This expenditure

\footnotetext{
${ }^{2}$ Uppal $(1992,1993)$ also considers an endogenous interest rate in his model of segmentation in the goods market.
} 
is funded by the initial dividend payout and the value of its initial share holding. In the second period after the state is realized, the household consumes the payout from its portfolio choice, which consists of stock dividends and interest income.

\subsection{Financial market structures}

Segmentation in the financial markets is modeled by imposing binary restrictions on the stock or bond holdings of households. We consider the possible variations of financial market structures whereby the home country chooses which of its financial markets to open from a current partially liberalized structure. We assume that foreign financial markets are completely open to all households. Specifically, we consider three types of financial market structures:

i. Complete liberalization of financial markets. Home stock and loans markets are open to foreign investment. There is no restriction on the portfolio variables $a_{i j}$ and $b_{i}$ for $i, j=1,2$.

ii. Closure of home stock markets. Only the stock market of the home country is closed to foreign investment $a_{21}=0$. There is no restriction on $a_{i 2}$ and $b_{i}$ for $i=1,2$.

iii. Closure of home financial markets. Both the stock and loans markets of the home country are closed to foreign investment $a_{21}=0$ and $b_{2}=0$. There is no restriction on holdings of the foreign stock $a_{i 2}$ for $i=1,2$.

The financial structures described under (ii) and (iii) prevents foreign capital inflows into the home country, which is the initial position of many emerging countries. Under the extreme structure of financial autarky $\left(s_{i i}=1, s_{i j}=0, b_{i}=0\right.$ for $\left.i, j=1,2\right)$, both capital inflows and outflows are restricted; that is, households cannot trade in any financial asset. In this economy, there is no risk sharing between the two households, nor is capital allocated efficiently between the two production technologies. Basak (1996) notes that households are better off with some financial openness than they are under financial autarky. This obtains in our model as well, since there is no imperfection or externality in the goods market. We therefore focus on the welfare implications of moving towards complete liberalization of financial markets (i) from the partially liberalized financial market structures (ii) and (iii).

\subsection{The firm's investment decision}


At time 0 , each firm chooses its dividend profile $\left\{d_{i}(0), d_{i}(1, s)\right\}$ and its investment $I_{i}$ to maximize the risk-adjusted present value of dividends given its funds constraint in each period. The firm $i$ 's maximization problem is written as

$$
\underset{d_{i}(0), d_{i}(1, s), I_{i}}{\operatorname{Max}} d_{i}(0)+\beta E_{0}\left[\phi_{i}(s) d_{i}(1, s)\right],
$$

subject to the time 0 and time 1 funds constraints

$$
\begin{aligned}
& d_{i}(0)=K_{i}-I_{i}, \\
& d_{i}(1, s)=y_{i}\left(I_{i}, s\right),
\end{aligned}
$$

where $\phi_{i}(s)$ is the pricing kernel, $K_{i}$ is the endowment of initial capital stock, and $y_{i}\left(I_{i}, s\right)$ is the firm's output.

Each firm uses its original shareholder's marginal rate of substitution of consumption between time 0 and time 1 to determine the present value of its dividends, so that

$$
\phi_{i}(s)=\beta\left(\frac{c_{i}(1, s)}{c_{i}(0)}\right)^{-\eta}
$$

When the firm is not traded internationally, the marginal rate of substitution of the original shareholder is obviously the appropriate pricing kernel to value the firm's profits. When the firm is traded, the investment decision is the same whether the original or the new shareholder's marginal rate of substitution is used to value the firm's profits, as discussed by Obstfeld and Rogoff (1996, p. 309). Essentially, the market clearing equilibrium ensures that both old and new shareholders' marginal rates of substitution are equal.

The funds constraints (5) and (6) assume that capital depreciates at a rate of $100 \%$. In addition, we interpret a firm's endowment of initial capital stock as the initial wealth of the country. Throughout our analysis, we assume the home country to be less wealthy than the foreign country, so that $K_{1}<K_{2}$.

Output in the funds constraint (6) is determined by a Cobb-Douglas production technology,

$$
y_{i}\left(I_{i}, s\right)=\theta_{i}(s) I_{i}^{\alpha_{i}}
$$


where $\theta_{i}(s)$ denotes a random technology shock, and $0<\alpha_{i}<1$ represents decreasing returns to scale in capital. In contrast to a linear production technology, here each additional unit of capital brings about a lower return. The technology shock $\theta_{i}(s)$ is assumed to follow a binomial distribution with mean $\mu_{i}>1$ and variance $\sigma_{i}^{2}$. The presence of international financial markets allows these shocks to be shared across countries.

Baxter and Crucini (1995) show that the specification of the technology shock process is important when examining incomplete markets. When shocks exhibit low persistence through time and when shocks spill over rapidly from one country to the other, the economy does not vary much with the degree of completeness. Otherwise, the economy differs substantially under different financial market structures. In our two-period model, shocks are obviously permanent. This suggests that the magnitude of our results on the wealth consequences of partial liberalization may be smaller in a stationary framework.

Under partial or perfect financial openness, households can use their financial assets both to share risk at a given time and to smooth out consumption over time while firms achieve an efficient allocation of capital to their production technology by using the households' marginal rates of intertemporal substitution as the pricing kernel. In our model, unlike the previous ones in this literature, the household's portfolio choice affects the allocation of capital in the economy. It is not clear whether each household is made better off or worse off by expanding the menu of financial assets under less than completely open financial markets, because introducing financial assets alters the investment decision, in addition to the risk sharing and consumption smoothing.

\section{The Equilibrium}

The solution to our model consists of the competitive equilibrium to the household's and firm's maximization problems. The first order conditions from household $i$ 's maximization problem characterize the risk-free rate and stock prices:

$$
\begin{aligned}
& E_{0}\left[\phi_{i}(s)(1+r)\right]=1, \\
& E_{0}\left[\phi_{i}(s) d_{i}(1, s)\right]=p_{i} .
\end{aligned}
$$

The household chooses its portfolio holdings so that the risk-adjusted expected returns on the stock and loans markets at time 1 equal the cost of one unit of funds invested at time 0 . 
The first order condition from firm i's maximization problem characterizes the investment decision:

$$
E_{0}\left\lfloor\phi_{i}(s) \alpha_{i} \theta_{i}(s) I_{i}^{\alpha_{i}-1}\right\rfloor=1
$$

The firm chooses its investment so that household $i$ 's risk-adjusted expected marginal product of capital at time 1 equals the cost of one unit of capital invested at time 0 . The firm therefore trades off a lower dividend in the initial period (due to a higher investment) with a higher dividend in the next period (due to a higher production from a higher investment).

The market clearing conditions in the financial markets are

$$
\begin{aligned}
& a_{11}+a_{21}=1, \\
& a_{12}+a_{22}=1, \\
& b_{1}+b_{2}=0 .
\end{aligned}
$$

The model cannot be solved analytically under general assumptions on preferences and technology. Much of our analysis is presented using numerical results. We numerically solve the model under the different financial market structures described in Section 2.2. The effect on welfare of each degree of liberalization is derived by substituting its competitive equilibrium back into the household's utility function. The optimal degree of liberalization is the one that commands the highest expected utility value.

\section{Main Results}

We investigate the conditions on the production technology under which a country benefits from fully liberalizing its financial markets. First, we examine the analytical solution to a special case of the economy without risk. We also perturb the special case by adding volatility to the production technology and solve for the equilibrium. Finally, we present and discuss the numerical results for a more general economy.

\subsection{Analytical results for a special case of the economy}


We solve the equilibrium in an economy where both countries are identical except for their initial capital endowment. In addition, the symmetric economy contains no risk $(\sigma=0)$, so risk sharing is irrelevant. The equilibrium investment decision equates the marginal products of capital across the two countries and attains an efficient allocation of capital. To further simplify, we assume that households have logarithmic preferences $(\eta=1)$. These assumptions allow an analytical solution to the model. The intuition behind the numerical results originates from this special case.

Without risk, all types of financial markets are equivalent so long as households can move their capital across the two production technologies. Except for financial autarky, all types of financial markets described in Section 2.2 fulfill this criterion. Two sets of solutions, under financial markets liberalized to any degree (i) to (iii) and under financial autarky, are presented below:

$\underline{\text { Liberalized Financial Markets }}$

$$
I_{i}=\frac{\alpha \beta\left(K_{i}+K_{j}\right)}{2(1+\alpha \beta)}
$$

$c_{i}(0)=\frac{K_{i}}{(1+\alpha \beta)}+\frac{\beta(1-\alpha)\left(K_{j}-K_{i}\right)}{2(1+\beta)(1+\alpha \beta)}$

$c_{i}(1, \cdot)=\mu\left(\frac{\alpha \beta}{1+\alpha \beta} \times \frac{K_{i}+K_{j}}{2}\right)^{\alpha} \times\left(\frac{2 K_{i}}{K_{i}+K_{j}}+\frac{\beta(1-\alpha)\left(K_{j}-K_{i}\right)}{(1+\beta)\left(K_{i}+K_{j}\right)}\right)$

$1+r_{\text {world }}=\mu \alpha\left(\frac{\alpha \beta}{1+\alpha \beta} \times \frac{K_{i}+K_{j}}{2}\right)^{\alpha-1}$ $\underline{\text { Financial Autarky }}$

$$
\begin{aligned}
& I_{i}=\frac{\alpha \beta K_{i}}{(1+\alpha \beta)} \\
& c_{i}(0)=\frac{K_{i}}{(1+\alpha \beta)} \\
& c_{i}(1, \cdot)=\mu\left(\frac{\alpha \beta K_{i}}{1+\alpha \beta}\right)^{\alpha} \\
& 1+r_{i}=\mu \alpha\left(\frac{\alpha \beta K_{i}}{1+\alpha \beta}\right)^{\alpha-1}
\end{aligned}
$$

As would be expected, it can be shown that both countries are better off with liberalization than with autarky. By comparing the equilibrium solutions, we observe that the consumption and risk-free rate solutions are identical under both financial market structures when the production technology exhibits constant returns to scale $(\alpha=1)$. In the more general case of decreasing returns $(\alpha<1)$, the investment and first-period consumption of the less wealthy country are higher, and its second-period consumption and the risk-free rate are lower under liberalized financial markets. In view of its lower endowment of initial capital, the less wealthy country is able to smooth its consumption profile. To reflect the liberalization, the world risk-free rate decreases relative to the risk-free rate of the less wealthy country under the autarky arrangement. 
In the symmetric economy without risk, we typically find a negative relationship between the welfare gain from liberalization for the less wealthy country and the capital share of the production technology $\alpha$. Intuitively, there is more to gain by reallocating capital from the wealthier country to the less wealthy country when each additional unit of capital invested in the technology faces a sharper decline in its marginal product. As the technology approaches constant returns, the welfare gain from liberalization is smallest, in accord with the findings of Basak (1996) and Devereux and Saito (1997).

The condition for the inverse relationship to hold for the less wealthy country is

$$
\frac{x-1}{1-\delta+\delta x}-2 \ln \left(\frac{1+x}{2}\right)>0
$$

where $x$ represents the wealth ratio between the two countries $K_{2} / K_{1}$, and $\delta$ summarizes the household parameters $(1-\alpha) \beta /(2(1+\beta))$. Because we assumed the home $(i=1)$ country is less wealthy, we know that $x>1$. We also know that $0<\delta<0.25$. Despite these restrictions on the parameters, it is not clear that condition (15) holds. Restating the condition, we obtain

$$
\frac{1}{2 \ln \left(\frac{1+K_{2} / K_{1}}{2}\right)}-\frac{1}{K_{2} / K_{1}-1}>\frac{(1-\alpha) \beta}{2(1+\beta)}
$$

From above, we know that the condition is more likely to hold for larger capital share values.

In fact, the condition holds for all reasonable capital share and wealth ratio values. Throughout the rest of the paper, we assume a time preference parameter of 0.98 . The following provides numerical examples of the range of values for which the welfare gain from liberalization for the less wealthy country decreases with the capital share in production:

The foreign country is $x$ times wealthier

$$
x=1.5
$$

$\underline{\text { Range of } \alpha \text { for the condition to hold }}$

$\alpha>0.0273$ 


$$
\begin{array}{ll}
x=2 & \alpha>0.0579 \\
x=3 & \alpha>0.1056 \\
x=4 & \alpha>0.1420 \\
x=5 & \alpha>0.1711
\end{array}
$$

We summarize our numerical result below.

Result 1: In a symmetric economy with no risk, the welfare gain from liberalization for the less wealthy country typically decreases with the share of capital in the production technology.

Figure 1 plots the welfare gain from liberalization for the less wealthy country in the symmetric economy with no risk. Figure 1 therefore abstracts from the role of risk sharing and captures the gain from the efficient capital allocation minus the loss in the difference between the borrowing rate abroad and the home reinvestment rate. Figure 1 shows an inverse relationship between this gain and the capital share in production $\alpha$, consistent with Result 1 .

Figure 1 is generated from the following symmetric economy. We assume that the home and foreign countries are endowed with $25 \%$ and $75 \%$ of the world capital stock. We fix the world capital stock to 1.5 so that the world interest rate is never negative in all our numerical results. Hence, $K_{1}=0.375$ and $K_{2}=1.125$. We also set the mean productivity in both countries to $9 \%(\mu=1.09)$.

Figure 1 displays no welfare gain when the production technology is linear $(\alpha=1)$. Because both countries experience the same mean productivity $\mu$, capital is not reallocated upon liberalization. Figure 1 displays a welfare gain only when the technology exhibits decreasing returns $(\alpha<1)$. Capital is reallocated more efficiently upon liberalization from the lower marginal product of capital of the wealthier country to the higher marginal product of the less wealthy country. In this case, the role of financial markets in allocating capital efficiently is no longer obliterated.

We can perturb the riskless, symmetric economy by adding symmetric technology shocks $\left(\sigma_{i}=\sigma\right)$ and solve the model with a second-order Taylor series expansion. Due the complexity of the resulting non-linear equations, we can approximate the solution only under the cases of autarky and complete liberalization of financial markets. In these cases, adding risk to the economy does not change the investment decision. Under autarky, there is no way to share the 
risk so that capital still remains in its home country. Under complete liberalization, risk is perfectly shared so that the economy still achieves the same efficient capital allocation as before. Consequently, Result 1 on the inverse relationship between the welfare gain of allocating capital efficiently and the capital share in production holds in the presence of risk.

\subsection{Numerical results for a more general economy}

More generally, in a world with risk but only partially liberalized markets, risk sharing is not perfect. A wealthier country can invest in the less wealthy country's production technology only by lending. The less wealthy country then reinvests the borrowed capital in its production technology and benefits from doing so when the reinvestment rate (i.e., its marginal product of capital) exceeds the rate at which it borrows abroad. Risk sharing therefore affects both the borrowing and the reinvestment rates.

First, the equilibrium borrowing rate is a risk-adjusted weighted average of the marginal product of capital in the two countries. Opening the financial markets of the less wealthy country with its associated shift in investment from the lower marginal product technology of the wealthier country to the higher marginal product technology causes the borrowing rate to increase. Second, when the production technology exhibits decreasing returns in capital, more investment in the less wealthy country decreases its marginal product of capital and hence its reinvestment rate. As a result, the gain arising from the difference between the borrowing and reinvestment rates is less likely to outweigh the loss of risk sharing that the less wealthy country incurs as it restricts access to its financial markets.

Due to the complexity of the system of non-linear equilibrium equations, we cannot obtain analytical solutions for a more general economy. We solve our model numerically for specific calibrations of the initial capital endowments $K_{i}$, as well as the means $\mu_{i}$ and standard deviations $\sigma_{i}$ of the productivity shocks under the three financial market structures described in Section 2.2. We report the welfare gain of the less wealthy country as the change in household utility from a partially liberalized financial market to a completely liberalized structure, divided by the household utility from the partially liberalized structure. Consequently, a positive (negative) value is associated with a gain (loss) in welfare from liberalization.

We provide numerical results for two specific economies. The first economy is symmetric and illustrates how the production technology is related to the endogenous interest 
rate. It serves to contrast our model of decreasing returns to scale with previous linear production technology research in this area. The second economy is asymmetric and analyzes the case for restricting China's financial markets to the rest of the world.

\subsubsection{Symmetric economy}

We continue to consider two countries that differ from each other only in terms of capital endowments. The purpose of studying this economy is to understand how the production technology, and hence the marginal product of capital, affects the endogenous interest rate. In our modeling framework as well as in previous work in this area by Basak (1996) and Devereux and Saito (1997), there is no friction in the real and financial markets. The only reason why a less wealthy country could be made better off with partial liberalization is that it can borrow capital abroad at a lower risk-free rate and reinvest the capital at home in the higher rate of return technology.

We continue to examine the same symmetric economy that generated Figure 1. In addition, we set the standard deviation of the productivity shocks to $2 \%(\sigma=0.02)$ and assume no correlation of shocks between countries. The numerical results are presented in Figures 2 and 3.

Figure 2 depicts the welfare gain for the less wealthy country, accounting for both risk sharing and efficient capital allocation. Figure 2 shows that the welfare gain from liberalization generally decreases with the capital share $\alpha$. The only exception occurs when $\alpha \rightarrow 1$ because of a discontinuity at the corner. This inverse relationship is again consistent with Result 1.

Figure 2 also shows that the less wealthy country always gains from complete liberalization, except when the technology is linear in capital. When the production technology exhibits decreasing returns in capital, the gain from borrowing capital at a lower risk-free rate and reinvesting it in a diminishing returns production does not outweigh the loss in risk sharing and the cost of inefficiently allocating capital.

Figure 3 plots the difference in borrowing costs for the less wealthy country between complete liberalization and partial liberalization. We measure this difference by $\left(r^{C}-r^{P}\right)$, where $r^{C}$ refers to the world risk-free rate under complete liberalization (i). $r^{P}$ also refers to the world riskfree rate under the closure of the home stock market (ii). However, under the closure of both home stock and loans markets (iii), $r^{P}$ refers to the expected stock return in the wealthier country because the less wealthy country can borrow only from the stock market (short-selling). 
Figure 3 shows that the difference in borrowing costs is positive. Because the world riskfree rate is a risk-adjusted weighted average of the marginal product of capital in the two countries, opening the financial markets of the less wealthy country puts more weight on its higher marginal product. The world risk-free rate therefore increases. Figure 3 also shows that the difference in borrowing costs increases with the share of capital in production. As with Figure 2, we observe a discontinuity as we approach the corner of a linear production technology. As would be expected, Figures 2 and 3 show that the welfare gain from liberalization varies inversely with the difference in borrowing costs. The less wealthy country benefits less from complete liberalization when the borrowing cost under partial liberalization is much lower than the borrowing cost under complete liberalization.

In summary, the numerical results so far suggest that the production technology plays an important role in studying the welfare gain from liberalizing financial markets and that a linear production may represent a very special case.

\subsubsection{China}

Our general equilibrium analysis is suitable to economic blocs such as Asia, Latin America, Europe, and North America, or big economies such as China, India, and the G7 countries. In this section, we choose to calibrate the parameters to resemble a two-country economy consisting of China and the advanced economy of the US and EU. At present, China's financial markets are still relatively segmented under the classification of A and B shares. Class A shares can be held by local investors only, while class B shares can be traded by both local and foreign investors. Moreover, the renminbi is still hard pegged to the US dollar and not traded as an international currency, making access to any markets within China more restricted than it appears. With China's accession to WTO and the potential size of its economy, the question whether or not to liberalize its financial markets becomes relevant.

From the data published in IMF's World Economic Outlook, we approximate China's share of the world capital stock to be one-third that of the US and EU ( $K_{l}=0.375$ and $\left.K_{2}=1.125\right)$. We recognize that China is more populous than the US and EU. We introduce labor $L$ as a factor of production with a share of $(1-\alpha)$, but we assume that it is a fixed and immobile endowment. From Asia-Pacific Economic Cooperation's Economic Report, Eurostat's Labour Force Survey, and U.S. Department of Labor's Bureau of Labor Statistics, we approximate China's share of the world labor endowment to be about 2.3 times that of the US and EU. We change the labor 
endowments from one unit for each country in the symmetric economy to $L_{1}=1.4$ and $L_{2}=0.6$. Using IMF forecasts of output growth in the two regions, we assume a mean productivity of $9 \%$ for China and $3 \%$ for the US and EU $\left(\mu_{1}=1.09\right.$ and $\left.\mu_{2}=1.03\right)$. For the past 10 years, the output volatilities for China and the advanced economies are estimated at $2 \%$ and $1 \%\left(\sigma_{l}=0.02\right.$ and $\sigma_{2}$ $=0.01$ ). The correlation of output between the two regions is roughly -0.25 . Finally, this applied case study requires more realistic preferences than logarithmic. Instead, we assume a risk aversion parameter $\eta$ of 2 . The calibration therefore represents China as a capital-poor (less wealthy) but labor-rich region with a relatively higher growth rate and riskier production technology.

\section{Scenario 1: $\quad$ Examining the effect of China's capital share}

We recognize that countries are relatively less capital intensive at an initial stage of development, while most advanced countries have attained a stable state of production technology. In this scenario, we examine how the welfare gain from complete liberalization varies as the production technology of the less wealthy country becomes more capital intensive. Following the empirical evidence of Stockman and Tesar (1995) suggesting that the capital share of G7 countries ranges from 0.35 to 0.5 , we fix $\alpha_{2}$ to 0.5 and vary $\alpha_{1}$. We also do not consider the linear technology in this section, as we will obtain a near-corner solution in equilibrium with the mean and volatility assumptions on the productivity shocks.

Figure 4 shows that the less wealthy region always loses from complete liberalization. This result contrasts with that for the symmetric economy in Figure 2, where the less wealthy country always gains from complete liberalization. Because the labor endowment and mean productivity of the less wealthy region are higher than those of the wealthier region, the marginal product of capital is also relatively larger. This magnifies the benefit from borrowing abroad and reinvesting at home. In fact, the figure indicates that China is better off closing both the stock and loans markets.

Figure 4 also shows that the less wealthy region has a greater incentive to restrict foreign access to its production as its capital share increases. As before, the plot is decreasing in the capital share $\left(\alpha_{1}\right)$. Similar to the greater labor endowment and the greater mean productivity of the less wealthy region, a greater capital share also increases the marginal product of capital, magnifying the benefit of restricting foreign access to its financial markets. 
Figure 5 plots the difference in borrowing costs for the less wealthy country between complete liberalization and partial liberalization. As for the symmetric economy in Figure 3, Figure 5 illustrates that the difference in borrowing costs is increasing in the capital share, reflecting the increasing difference between the borrowing and reinvestment rates.

Because China is expected to become more capital intensive over time, the gain from restricting access to its financial markets is likely to increase.

Scenario 2: $\quad$ Examining the effects of China's population and productivity

In this scenario, we recognize that China is less capital intensive than the US and EU by setting $\alpha_{1}=0.35$ and $\alpha_{2}=0.5$. We investigate how the welfare gain from liberalization varies with China's labor endowment $L_{l}$ and its mean productivity $\mu_{1}$.

Figure 6 shows that the less wealthy country gains from complete liberalization when its labor endowment is low enough. Keeping the domestic stock market closed to foreign investment becomes optimal only when the labor endowment exceeds roughly $65 \%$ of the world's labor. Figure 7 illustrates that the less wealthy country always loses from complete liberalization, irrespective of its mean productivity. Figures 6 and 7 show that the welfare gain decreases with the labor endowment and the mean productivity. Both labor and productivity increase the marginal product of capital and thus increase the benefit of borrowing abroad to reinvest at home.

China's large population and its high productivity may explain its partially liberalized financial structure.

Our results on China thus far are summarized below:

Result 2: A less wealthy country is more likely to benefit from partial liberalization than from complete liberalization when capital it borrows abroad at the lower risk-free rate is reinvested at home in a production technology that exhibits a higher marginal product, through a larger capital share, a bigger labor endowment, or a higher mean productivity.

\section{Scenario 3: $\quad$ Examining the effect of foreigners' holdings in China}

In this scenario, we continue to assume that China is less capital intensive than its wealthier counterpart $\left(\alpha_{1}=0.35\right.$ and $\left.\alpha_{2}=0.5\right)$. We examine how the welfare gain from liberalization varies 
with the initial holdings of foreigners in China. We no longer assume that the home household initially holds the entire claim to the home production.

Figure 8 shows that a partially liberalized structure where China restricts foreign access to its domestic financial markets remains optimal so long as foreign investors initially hold less than approximately $30 \%$ of Chinese stocks. However, as the proportion increases beyond $30 \%$, it becomes optimal for China to liberalize its financial markets completely. When foreigners own enough of the home production, the larger capital availability makes the reinvestment of borrowed funds less attractive.

The small initial holdings of foreigners in China may explain its partially liberalized financial structure.

Our last result on China is summarized below:

Result 3: A less wealthy country is more likely to benefit from partial liberalization than from complete liberalization when the wealthier country initially owns less of the less wealthy country's production, so that the difference between the borrowing rate abroad and the reinvestment rate at home can be sufficiently large.

\section{Conclusion}

Our results complement those of Basak (1996) and Devereux and Saito (1997). According to these previous studies which assume a linear production technology, a less wealthy country may be better off with partial liberalization if it can borrow abroad at a lower risk-free rate and invest at home at a higher rate of return.

Our numerical results emphasize that the production technology importantly affects the welfare gain from liberalizing financial markets. Specifically, the marginal product of capital affects the reinvestment rate of borrowed capital and therefore the welfare gain from liberalization. When the production technology exhibits decreasing returns in capital, the optimal financial market structure for the less wealthy country is likely to be complete liberalization. However, when the less wealthy country is endowed with more labor, when it is expected to be more productive, or when foreigners' holdings are smaller, then partial liberalization becomes optimal. The last three scenarios may explain why China restricts access to its financial markets. 


\section{Appendix - The Special Case of Linear Production Technology}

In this appendix, we show that an investment model is equivalent to a portfolio model in the special case of linear production technology. The budget constraints of the home household $(i=1)$ in an investment model are

$$
\begin{aligned}
& c_{1}(0)+\sum_{j=1}^{2} I_{1 j}+b_{1}=K_{1}, \\
& c_{1}(1, s)=\sum_{j=1}^{2} \theta_{1}(s) I_{1 j}^{\alpha}+b_{1}(1+r),
\end{aligned}
$$

where $I_{i j}$ is the investment of household $i$ in firm $j$ 's production technology. The budget constraints of the home household in the portfolio model are presented in (2) and (3).

For both models to be equivalent, the payout from home (foreign) investment must equal the payout from the portfolio choice in home (foreign) stock for each household. This implies that

$$
\begin{aligned}
& \theta_{j}(s) I_{1 j}^{\alpha}=a_{1 j}\left[\theta_{j}(s) I_{j}^{\alpha}\right], \\
& \theta_{j}(s) I_{2 j}^{\alpha}=a_{2 j}\left[\theta_{j}(s) I_{j}^{\alpha}\right], \quad j=1,2 .
\end{aligned}
$$

In a two-country economy, the home and foreign household investments in firm $j$ 's production must aggregate to the world investment: $I_{l j}+I_{2 j}=I_{j}$. Using this aggregation and the market clearing condition that $a_{1 j}+a_{2 j}=1$, equations (A3) and (A4) sum to

$$
\theta_{j}(s)\left(I_{1 j}^{\alpha}+I_{2 j}^{\alpha}\right)=\theta_{j}(s)\left(I_{1 j}+I_{2 j}\right)^{\alpha} \text {. }
$$

When the production technology is linear in capital $(\alpha=1)$, a household's investment decision is equivalent to its portfolio decision. 


\section{References}

Backus, D.K., P.J. Kehoe, and F. Kydland, 1992, "International real business cycles," Journal of Political Economy 100, 745-775.

Basak, S., 1996, “An intertemporal model of international capital market segmentation," Journal of Financial and Quantitative Analysis 31, 161-188.

Baxter, M. and M. Crucini, 1995, "Business cycles and the asset market structure of foreign trade," International Economic Review 36, 821-854.

Bekaert, G., C.R. Harvey, and C. Lundblad, 2004, "Does financial liberalization spur growth?" Journal of Financial Economics, forthcoming.

Bergstrom, C., K. Rydqvist, and P. Sellin, 1993, "Asset pricing with in- and outflow constraints: Theory and empirical evidence from Sweden," Journal of Business Finance and Accounting 20, 865-869.

Brennan, M.J. and B. Solnik, 1989, "International risksharing and capital mobility," Journal of International Money and Finance 8, 359-373.

Cole, H. and M. Obstfeld, 1991, "Commodity trade and international risk sharing: How much do financial markets matter?” Journal of Monetary Economics 28, 3-24.

Devereux, M.B. and K.M. Lee, 1999, "Endogenous trade policy and the gains from international financial markets," Journal of Monetary Economics 43, 35-59.

Devereux, M.B. and M. Saito, 1997, "Growth and risk-sharing with incomplete international assets markets," Journal of International Economics 42, 453-481.

Edwards, S., 2001, "Capital mobility and economic performance: Are emerging economies different?" in H. Siebert (ed.), The World's New Financial Landscape: Challenges for Economic Policy (Springer-Verlag, Berlin), 219-244.

Errunza, V. and E. Losq, 1989, "Capital flow controls, international asset pricing and investors' welfare: A multi-country framework," Journal of Finance 41, 897-914.

Errunza, V. and E. Losq, 1985, "International asset pricing under mild segmentation: Theory and test," Journal of Finance 40, 105-124.

Eun, C. and S. Janakiramanan, 1986, "A model of international asset pricing with a constraint on foreign equity ownership," Journal of Finance 41, 1025-1037.

Hietala, P.T., 1989, "Asset pricing in partially segmented markets: Evidence from the Finnish market," Journal of Finance 44, 897-914.

Kim, J., S.H. Kim, and A. Levine, 2003, "Patience, persistence, and welfare costs of incomplete markets in open economies," Journal of International Economics 61, 385-396. 
Kose, M.A., 1995, "Welfare implications of international risk sharing," University of Iowa Working Paper.

Kubler, F., and K. Schmedders, 2001, "Incomplete markets, transitory shocks, and welfare," Review of Economic Dynamics 4, 747-766.

Levine, R. and S. Zervos, 1998, "Stock markets, banks and economic growth," American Economic Review 88, 537-338.

Lewis, K.K., 1996, "Consumption, stock returns, and the gains from international risksharing," NBER Working Paper no. 5410.

Mendoza, E., 1995, "The terms of trade, the real exchange rate and economic fluctuations," International Economic Review 36, 101-137.

Merton, R., 1987, "A simple model of capital market equilibrium with incomplete information," Journal of Finance 42, 483-510.

Obstfeld, M., 1995, "International capital mobility in the 1990s," in P.B. Kenen (ed.), Understanding Interdependence (Princeton University Press: Princeton), 201-261.

Obstfeld, M., 1994a, "Evaluating risky consumption paths: The role of intertemporal substitutability," European Economic Review 38, 1471-1486.

Obstfeld, M., 1994b, "Risk-taking, global diversification, and growth," American Economic Review 84, 1310-1329.

Obstfeld, M. and K. Rogoff, 1996, Foundations of International Macroeconomics (MIT Press, Cambridge, MA).

Rajan, R. and L. Zingales, 2003, "The great reversals: The politics of financial development in the $20^{\text {th }}$ century," Journal of Financial Economics 69, 5-50.

Sellin, P. and I. Werner, 1993, "International investment barriers in general equilibrium," Journal of International Economics 34, 137-151.

Shiller, R.J. and S. Athanasoulis, 1995, "World income components: Measuring and exploiting international risk sharing opportunities," NBER Working Paper no. 5095.

Subrahmanyam, M.G., 1975a, "On the optimality of international capital market integration," Journal of Financial Economics 2, 3-28.

Subrahmanyam, M.G., 1975b, "International capital market equilibrium and investor welfare with unequal interest rates," in E.J. Elton and M.J. Gruber (eds.), International Capital Markets (North Holland: Amsterdam).

Stockman, A.C. and L. Tesar, 1995, "Tastes and technology in a two-country model of the business cycle: Explaining international co-movements," American Economic Review 85, 168185. 
Tesar, L.L., 1995, "Evaluating the gains from international risk sharing," Carnegie-Rochester Conference Series in Public Policy 42, 95-143.

Uppal, R., 1993, "A general equilibrium model of international portfolio choice," Journal of Finance 48, 529-553.

Uppal, R., 1992, "Deviations from purchasing power parity and capital flows," Journal of International Money and Finance 11, 126-144.

van Wincoop, E., 1999, "How big are potential welfare gains from international risksharing?" Journal of International Economics 47, 109-135.

van Wincoop, E., 1996, "A multi-country real business cycle model with heterogeneous agents," Scandinavian Journal of Economics 98, 233-251.

van Wincoop, E., 1994, "Welfare gains from international risksharing," Journal of Monetary Economics 34, 175-200. 


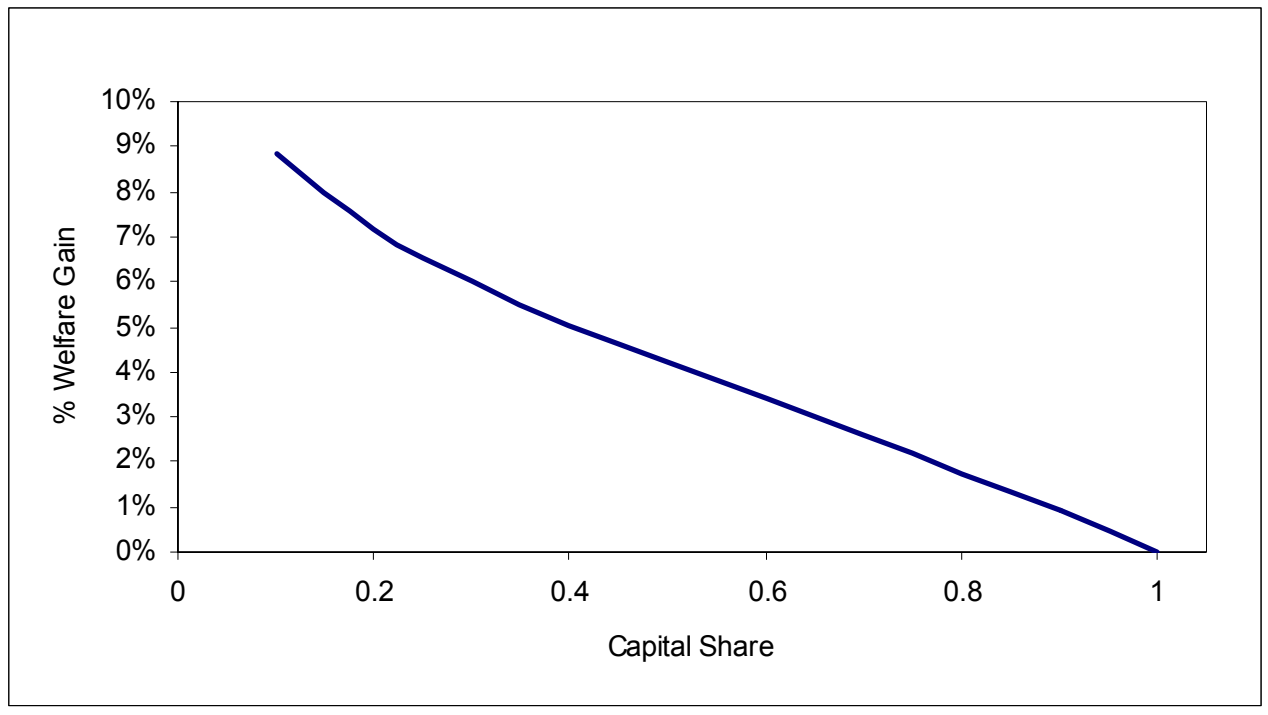

Figure 1. Welfare gain from reallocating capital efficiently upon liberalization for the less wealthy country, as a function of its capital share.

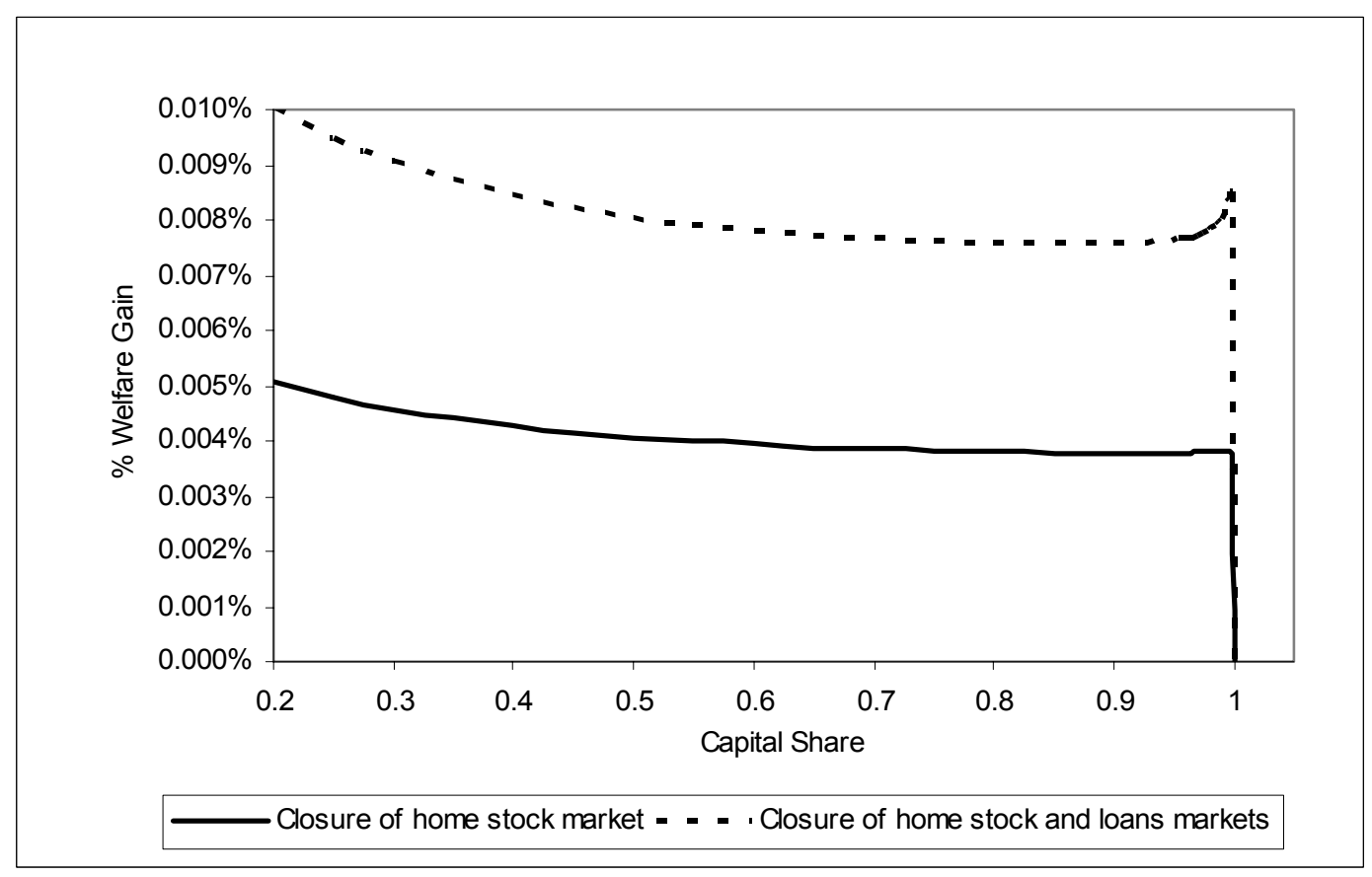

Figure 2. Welfare gain from complete liberalization for the less wealthy country, as a function of its capital share. 


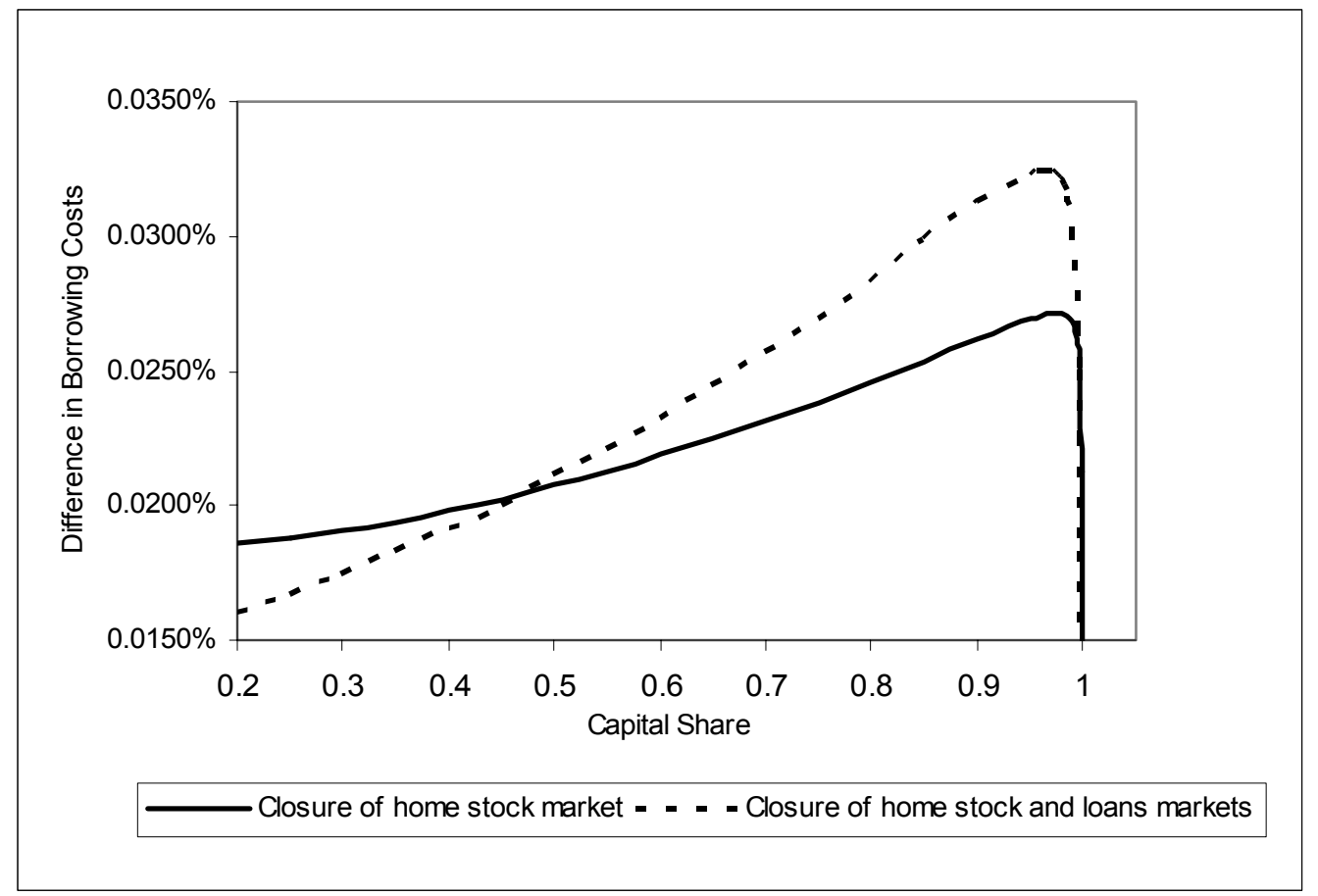

Figure 3. Difference in borrowing costs between complete liberalization and partial liberalization for the less wealthy country, as a function of its capital share.

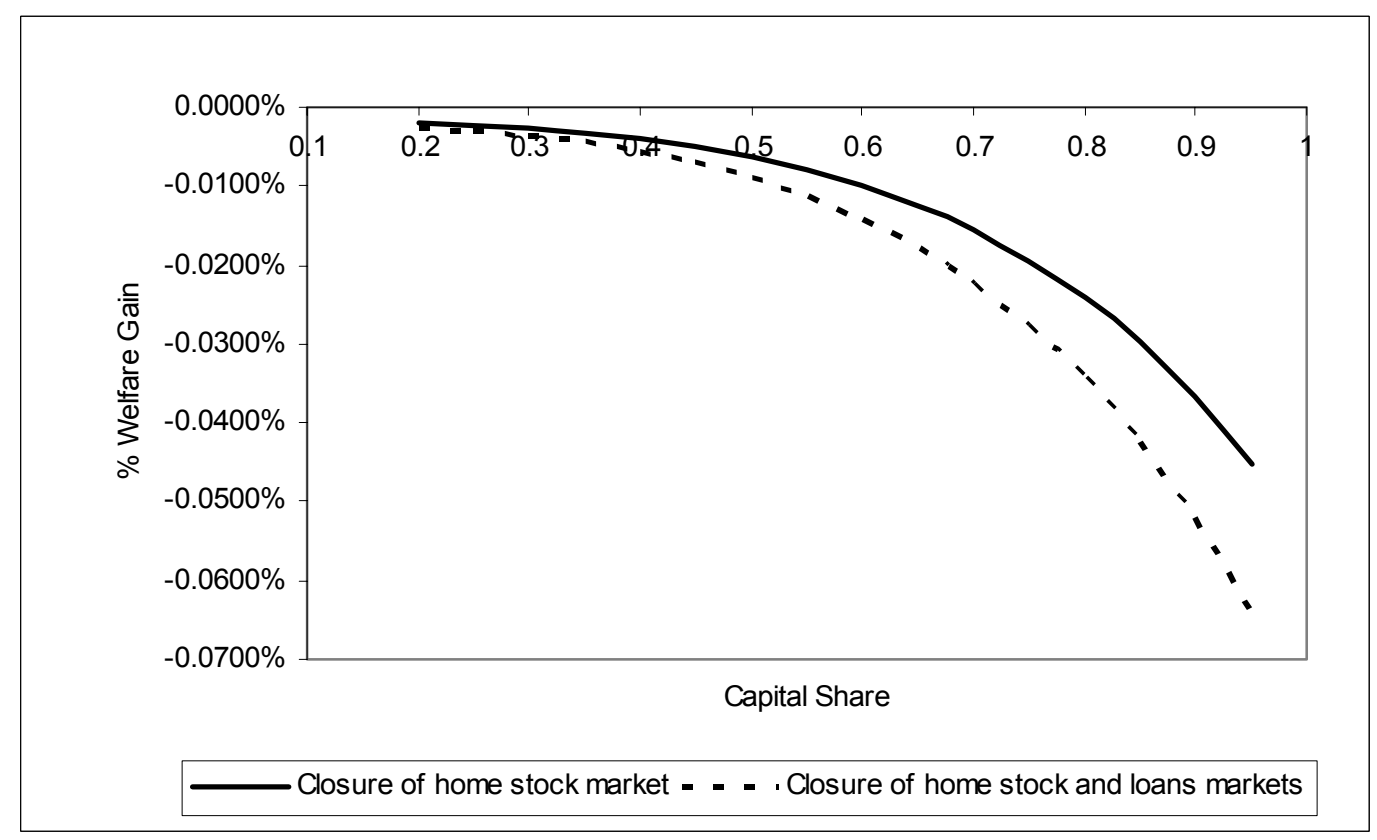

Figure 4. Welfare gain from the complete liberalization of China, as a function of its capital share. 


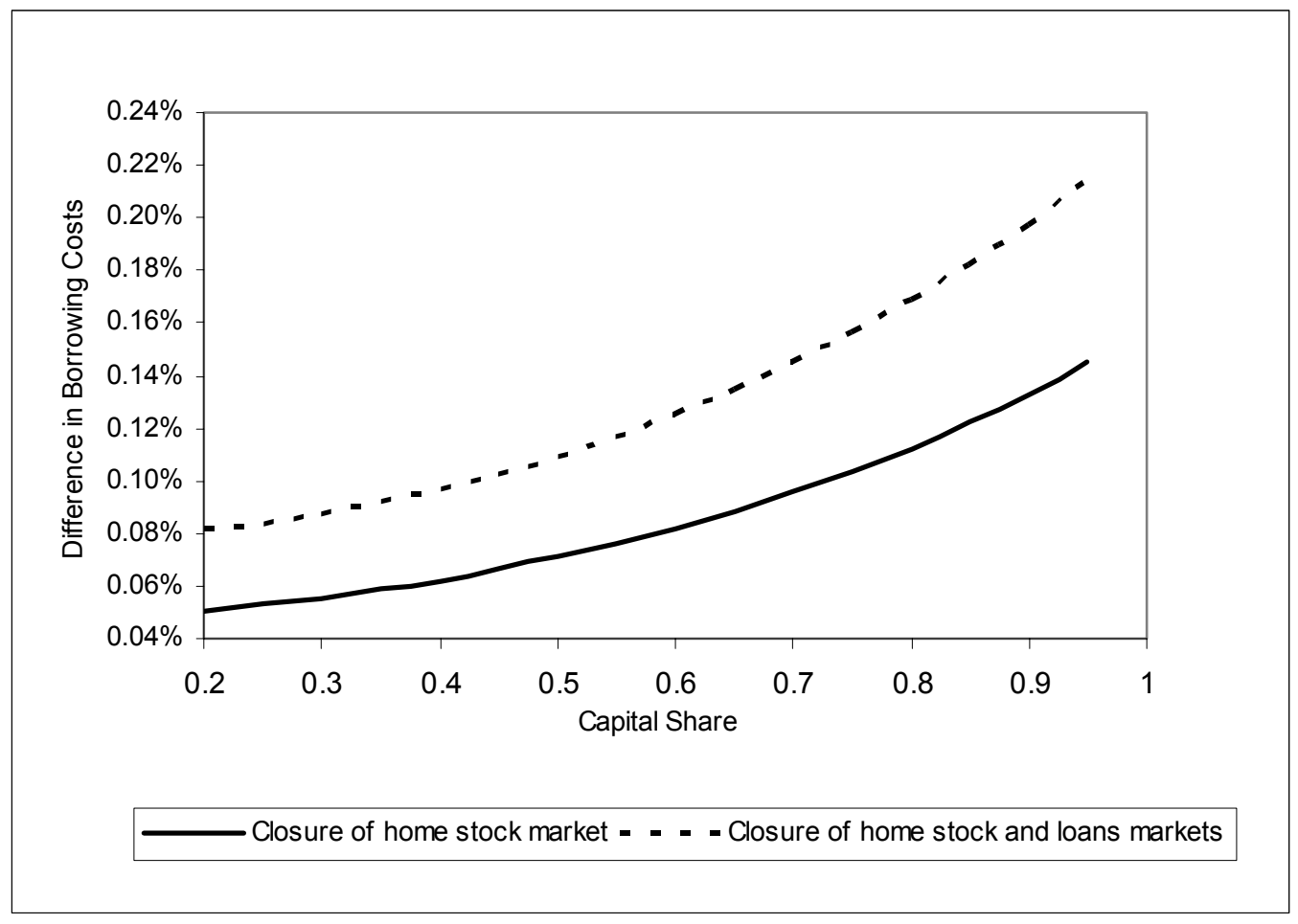

Figure 5. Difference in borrowing costs between complete liberalization and partial liberalization in China, as a function of its capital share.

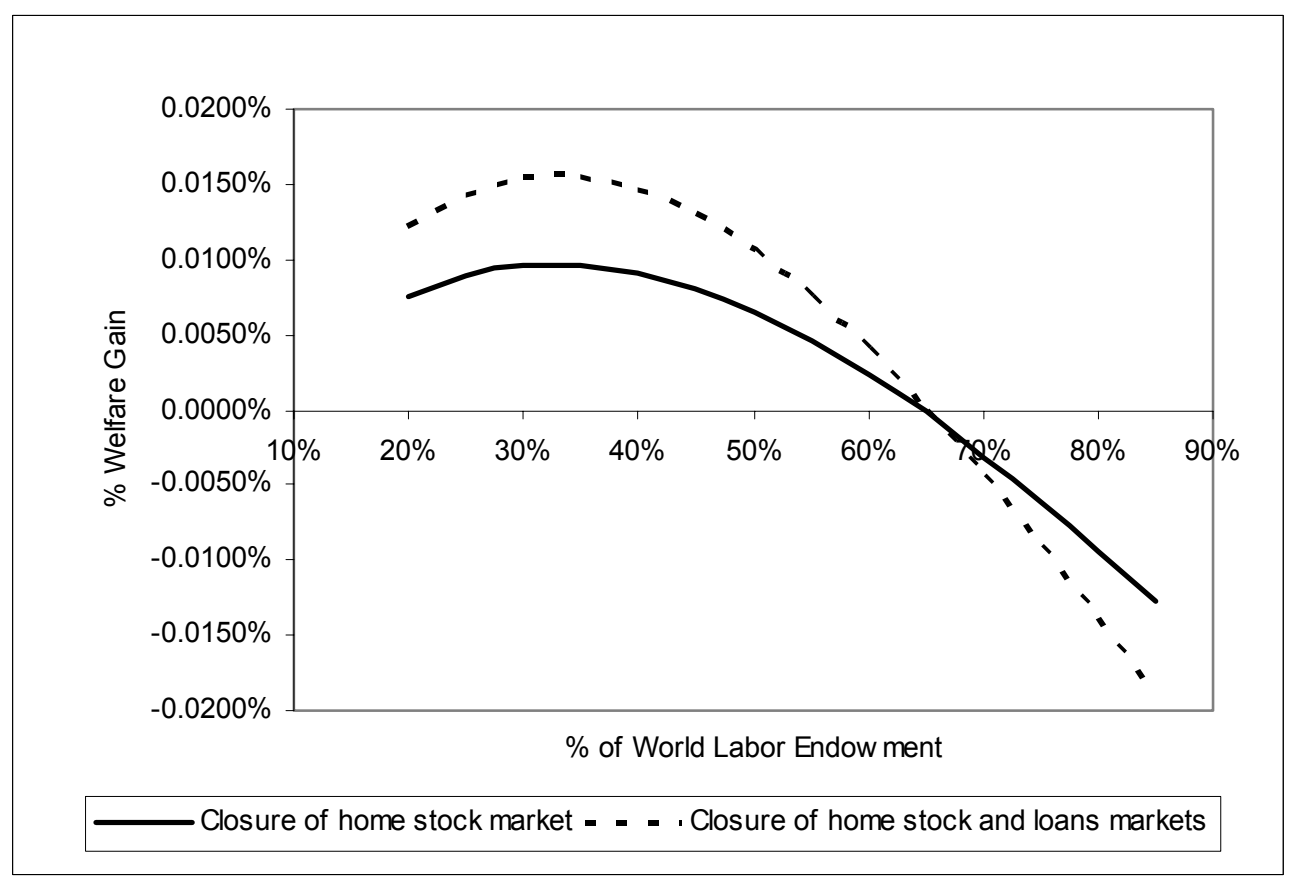

Figure 6. Welfare gain from the complete liberalization of China, with capital shares fixed at $\alpha_{1}=0.35$ and $\alpha_{2}=0.5$, as a function of its percentage of the world labor endowment. 


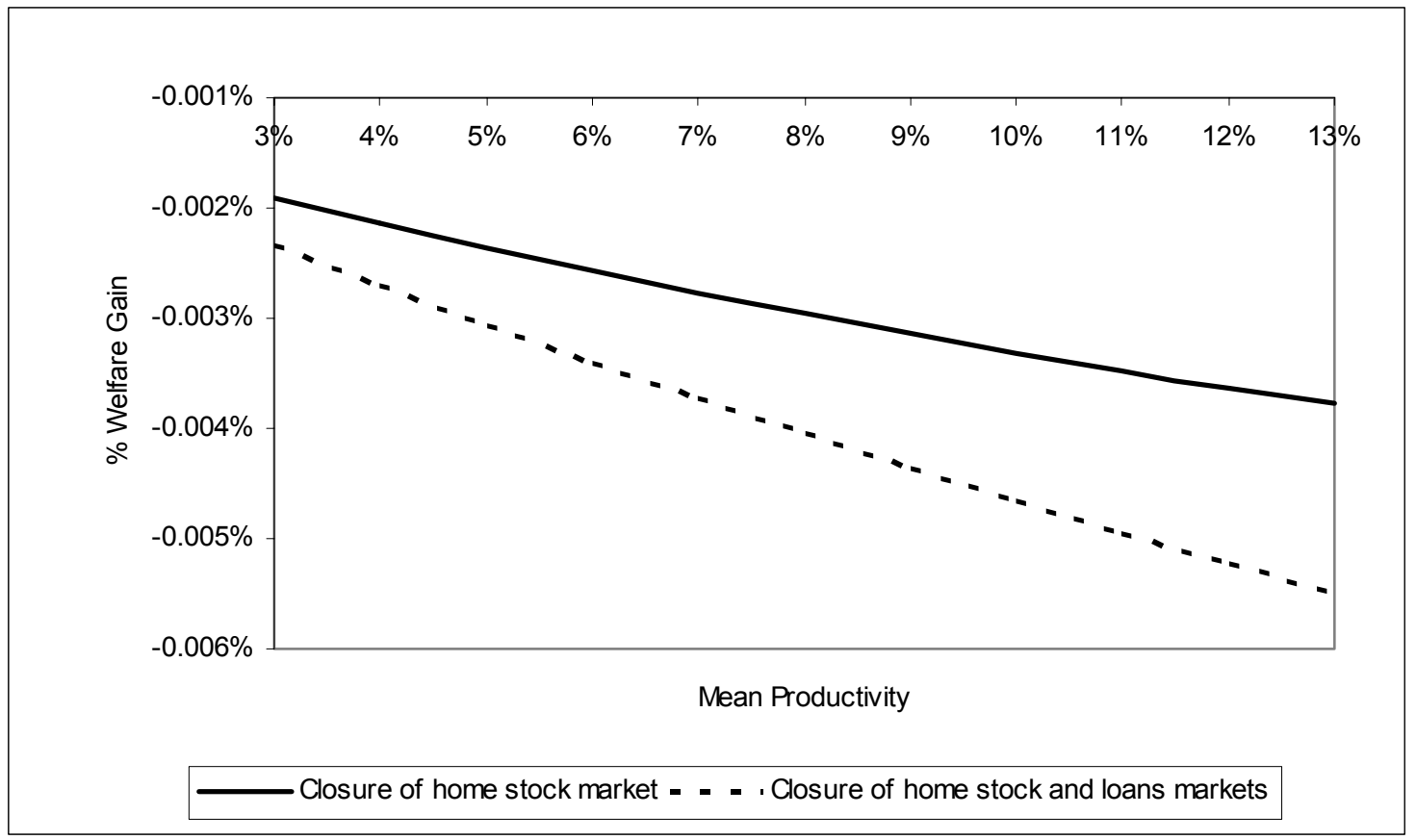

Figure 7. Welfare gain from the complete liberalization of China, with capital shares fixed at $\alpha_{1}=0.35$ and $\alpha_{2}=0.5$, as a function of its mean productivity.

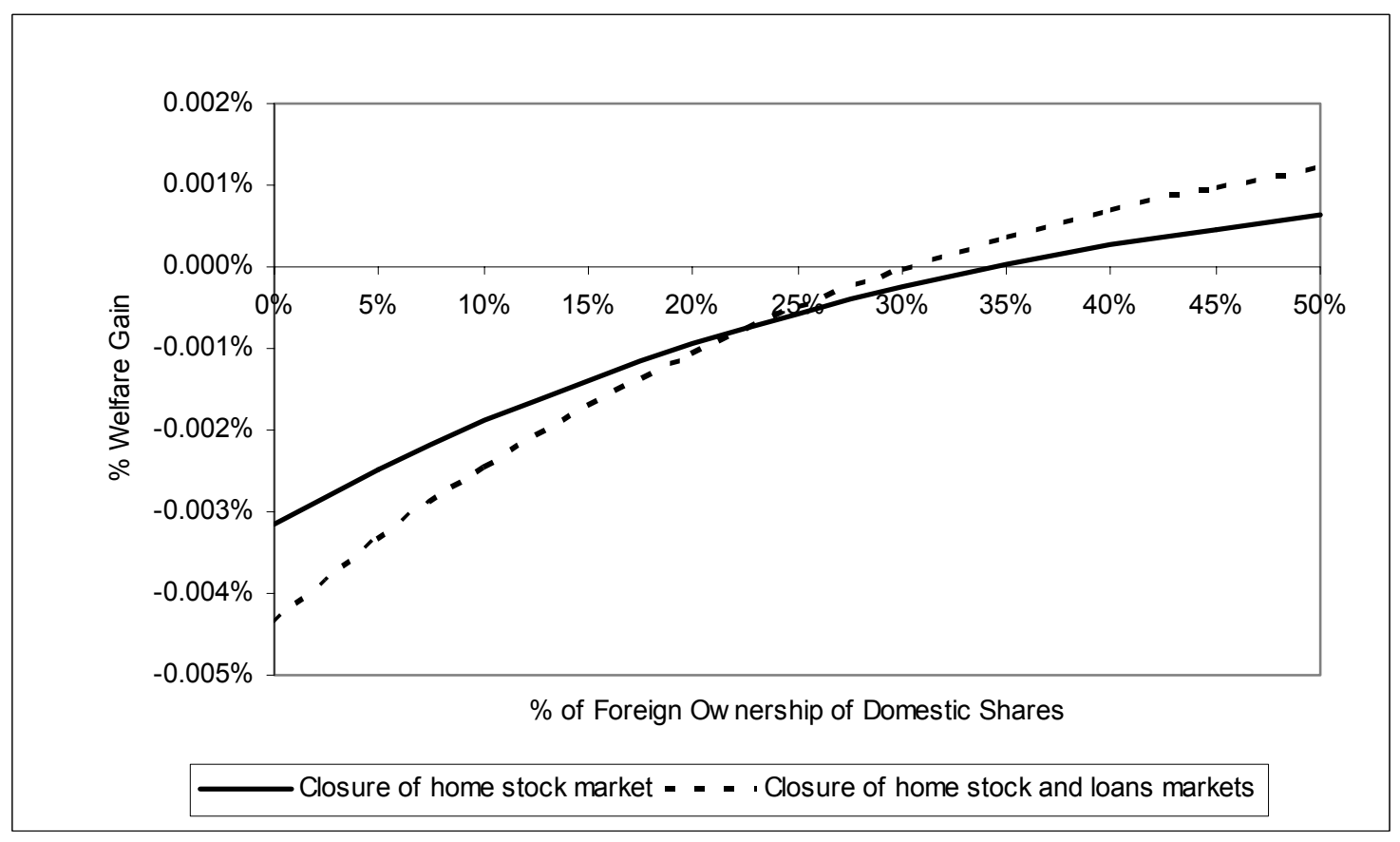

Figure 8. Welfare gain from the complete liberalization of China, with capital shares fixed at $\alpha_{1}=0.35$ and $\alpha_{2}=0.5$, as a function of the percentage of foreigners' initial holdings. 